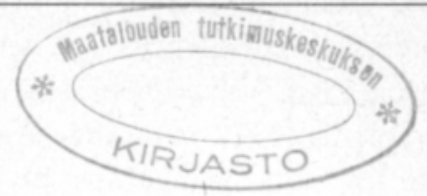

\title{
Environmental and genetic variation in protein content of peas under northern growing conditions and breeding implications
}

\author{
REIJO KARJALAINEN and *SALME KORTET \\ Departments of Plant Pathology and Plant Breeding, University of Helsinki \\ SF-00710 Helsinki, Finland
}

*Department of Plant Breeding, Agricultural Research Centre, SF-31600 Jokioinen, Finland

\begin{abstract}
Association of protein content in peas with climatic factors was studied on data based on official cultivar trials at six locations in southern Finland in 1978-1985. Correlation and step-wise multiple linear regression methods were used to define the main climatic variables affecting protein content.

Correlation studies showed that protein content was significantly and positively associated with temperature sum and mean June temperature and significantly negatively correlated with July precipitation. Regression analysis indicated that climatic factors accounted for $25 \%-70 \%$ of the total variation in protein content. Temperature sum and precipitation in July were the most important independent variables explaining protein variation. The role of environmental factors for protein variation and its implications for the improvement of protein content by plant breeding is discussed.
\end{abstract}

Index words: peas, protein variation, climatic factors, plant breeding

\section{Introduction}

Legumes provide about $10 \%$ of the world's supply of protein (Gridley and Evans 1979, Matthews and Arthur 1985). Today there is an increasing interest in utilizing legume protein in animal feeding mainly because legumes have the ability to fix nitrogen biologically and simultaneously produce abundant protein. In addition, failures in breeding cereals for better protein crops have focused more attention on grain legumes, which naturally contain high amounts of protein with high biological value in terms of amino acid composition. In the past ten years particular attention has been given on peas as an important future protein crop in Europe because remarkable advances in improving yield stability have been achieved. Breeding success has been based on utilizing mutant genes which affect the development of tendrils, leaflets and stipules (KuJAL.A 1953, DAviEs 1977) so that breeders have been able 
to produce leafless and semileafless peas. These types of peas have better lodging resistance than conventional peas, which means considerable savings in harvesting costs.

The protein content of peas is a heritable trait (PEsOla 1955) as well as its protein quality (Holt and Sosulski 1979), and they are obvious targets for improvement by breeding. However, available data (SNOAD 1980, MATTHEWS and ARTHUR 1985) suggest that protein breeding in peas is likely to be difficult. This assumption is based on observations (ALIKhan and Youngs 1973, Wolf 1975) that protein content is also strongly affected by environmental factors.

The present paper is a continuation of a previous report (KARJALAINEN and HovineN 1981) and is based on more extensive data. The main purpose of this study is to explain the variation in protein content of peas on the basis of climatic variables and to discuss problems related to protein improvement by plant breeding under northern growing conditions.

\section{Materials and methods}

The present data based on official cultivar trials at the following six locations in 19781985: Agricultural Research Centre, Departments of Plant Husbandry and Plant Breeding (Jokioinen), Agricultural Research Stations of Satakunta (Kokemäki), Kymenlaakso (Anjala), Häme (Pälkäne), and Lounais-Suomi (Mietoinen) (Table 1). Environmental conditions varied widely between different years and locations. Nitrogen levels varied from 16 to $80 \mathrm{~kg} / \mathrm{ha}$.

Climatic variables were based on data collected at the Agricultural Research Stations, and statistical calculations, correlation analyses, and step-wise multiple linear regression analyses were computed by standard procedures.

\section{Results}

\section{Correlation studies}

Correlation data based on all varieties in- dicate that protein content is clearly positively associated with plant height, growing time, flowering duration, lodging, seed yield, and protein yield (Table 2). Seed weight shows no clear association with protein content. Association of protein content with some climatic factors reveals that temperature sum and mean June temperature are significantly positively correlated with protein content, while the correlation with July precipitation was significantly negative. Other climatic factors did not have much influence on protein content.

Correlation analysis of single varieties confirms the data based on all varieties since again protein content is positively associated with plant height, growing time, lodging, and seed and protein yield. Association of seed weight with protein content is inconsistent as some cultivars, such as Kiri and Simo, showed significant positive correlations, while for others the association was weak. However, in the case of Kiri and Simo the high correlations might simply be due to chance caused by the small number of trials. In general, it appears that seed weight is only weakly correlated with protein content. Association of climatic factors with protein content appears to be similar as for all varieties. Mean June temperature is for all varieties positively correlated with protein content, while mean temperatures in July and August had only a small influence on it. Temperature sum and protein content were clearly positively correlated for all cultivars except for Simo, which, however may again be due to chance because of limited material. In general, rainfall appears to have negative influence on protein content, and particularly precipitation in July is often significantly negatively associated with protein content (Table 2).

\section{Regression studies}

In order to explain in more detail the climatic effects on protein content, step-wise regression methods with the probability of $\mathrm{F}=$ 0.05 were employed. At the first stage, in- 
Table 1. Number of observations on different cultivars at various trial locations. Data based on trial results published by the Agricultural Research Centre, Department of Plant Breeding (Kjo), Department of Plant Husbandry (Kvo), and the following Research Stations, Satakunta (Sat), Kymenlaakso (Kym), Häme (Häm), and Lounais-Suomi (Lou) in 1978-1985.

\begin{tabular}{|c|c|}
\hline $\begin{array}{l}\text { Number of } \\
\text { observations }\end{array}$ & $\begin{array}{l}\text { Number of } \\
\text { observations }\end{array}$ \\
\hline Proco Tot. 43 & Rondo Tot. 40 \\
\hline 1978 Lou, Sat, Kym, Häm & 1978 Lou, Sat, Kym, Häm \\
\hline 1979 Kvo, Kjo, Lou, Sat, Kym, Häm & 1979 Kvo, Kjo, Lou, Sat, Kym, Hăm \\
\hline 1980 Kvo, Lou, Sat, Kym, Häm & 1980 Kvo, Lou, Sat, Kym, Häm \\
\hline 1981 Kjo, Lou, Sat, Kym, Häm & 1981 Kjo, Lou, Sat, Kym, Häm \\
\hline 1982 Kvo, Kjo, Lou, Sat, Kym, Häm & 1982 Kvo, Kjo, Lou, Sat, Kym, Kym, Häm \\
\hline 1983 Kvo, Kjo, Lou, Sat, Kym, Häm & 1983 Kvo, Kjo, Lou, Sat, Kym, Häm \\
\hline 1984 Kjo, Lou, Sat, Kym, Häm & 1984 Kvo, Lou, Sat, Häm \\
\hline 1985 Kvo, Kjo, Lou, Sat, Kym, Häm & 1985 Kvo, Kjo, Lou, Sat \\
\hline Filby Tot. 34 & Hemmo Tot. 40 \\
\hline 1978 Lou, Kym & 1978 Lou, Sat, Kym, Häm \\
\hline 1979 Kvo, Lou & 1979 Kvo, Kjo, Lou \\
\hline 1980 Kvo, Lou & 1980 Kvo, Lou, Sat, Kym, Häm \\
\hline 1981 Kjo, Lou, Sat, Kym, Häm & 1981 Kjo, Lou, Sat, Kym, Häm \\
\hline 1982 Kvo, Kjo, Lou, Sat, Kym, Häm & 1982 Kvo, Kjo, Lou, Sat, Kym, Häm \\
\hline 1983 Kvo, Kjo, Lou, Sat, Kym, Häm & 1983 Kvo, Kjo, Lou, Sat, Kym, Häm \\
\hline 1984 Kjo, Lou, Sat, Kym, Häm & 1984 Kjo, Lou, Sat, Kym, Häm \\
\hline 1985 Kvo, Kjo, Lou, Sat, Kym, Häm & 1985 Kvo, Kjo, Lou, Sat, Kym, Häm \\
\hline Hertta Tot. 24 & Kiri Tot. 19 \\
\hline 1978 Lou & 1978 Lou, Sat, Kym, Häm \\
\hline 1979 Kvo, Kjo, Lou & 1979 Kvo, Kjo, Lou, Sat, Kym, Häm \\
\hline 1980 Lou & 1980 Kvo, Lou, Kym, Häm \\
\hline 1981 Kjo, Lou, Sat, Kym, Häm & 1981 Kjo, Häm \\
\hline 1982 Kvo, Kjo, Lou, Sat, Kym, Häm & 1982 Kjo \\
\hline 1983 Kvo, Kjo, Lou, Sat, Kym, Hăm & 1983 Kjo \\
\hline 1984 Kjo & 1984 Kjo \\
\hline 1985 Kjo & \\
\hline \multicolumn{2}{|l|}{ Simo Tot. 18} \\
\hline 1978 Lou, Sat, Kym, Häm & \\
\hline 1979 Kvo, Kjo, Lou, Sat, Kym, Häm & \\
\hline 1980 Kvo, Lou, Sat, Kym, Hăm & \\
\hline 1981 Kjo & \\
\hline 1982 Kvo, Kjo & \\
\hline
\end{tabular}

dependent variables incorporated in the regression models were mean temperatures in June, July, and August, as well as precipitations in June, July, and August. At the second stage, temperature sum was incorporated into the model. The results based on all varieties (Table 3$)$ show that regression equation $(\mathrm{F}=$ $22.36^{* * *}$ ) including variables July precipitation and June and July mean temperatures accounted for $25.6 \%$ of the total variation in protein content. Precipitation in July alone explained for $10.4 \%$ of the variation.
Data based on single varieties reveal that cultivars Hemmo and Rondo show similar patterns, and July precipitation and temperature accounted for $28.5 \%$ and $27.6 \%$, respectively, of the total variation in protein content. July precipitation accounted for $16.3 \%$ and $17.5 \%$ of the protein variation in Hemmo and Rondo, respectively. Computations based on early cultivar Proco indicated that July precipitation had the largest effect on protein content, $24.4 \%$, as the regression model, including July precipitation 


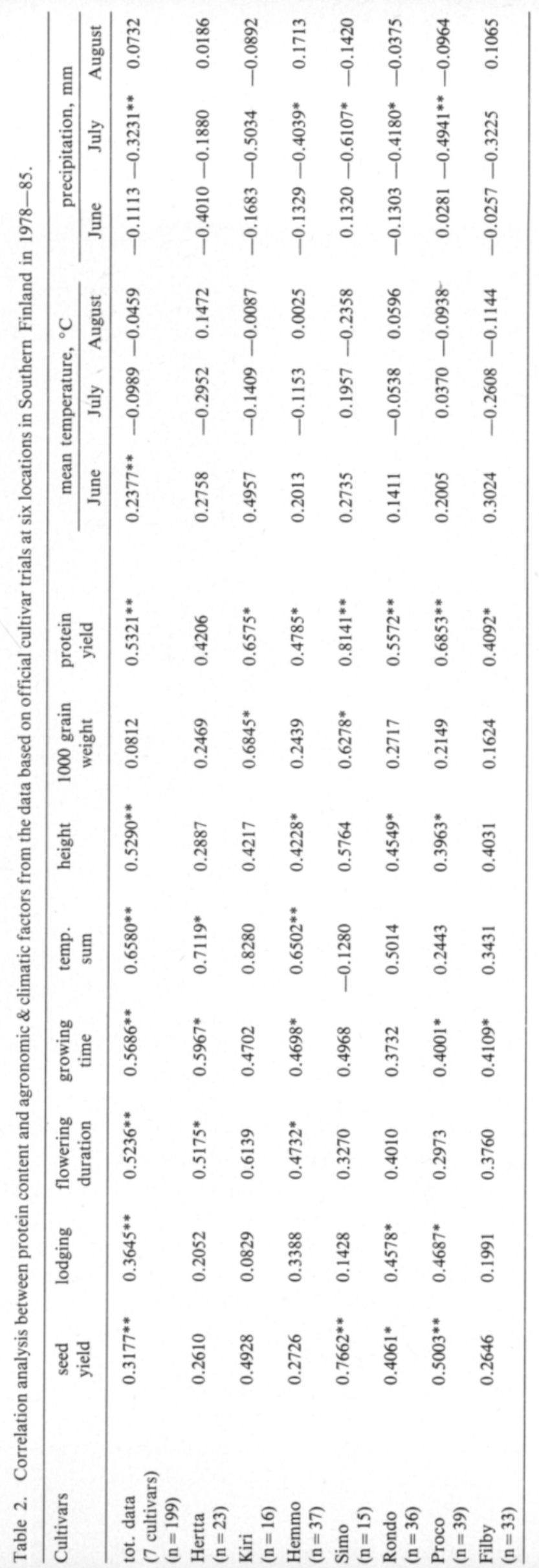


Table 3. Regression analysis on climatic factors affecting protein content in peas from the data based on official cultivar trials at six locations in Southern Finland in 1978-85.

\begin{tabular}{|c|c|c|c|c|c|}
\hline Cultivars & $\mathrm{n}$ & Regression equation (probability of $\mathrm{F}$ in $=0.050$ ) & $F$ value & df & $\mathbf{R}^{2}$ \\
\hline $\begin{array}{l}\text { tot. data } \\
\text { ( } 7 \text { culti- } \\
\text { vars) }\end{array}$ & 199 & $\mathrm{y}=34.636-0.038 \cdot$ July $-0.968 \cdot$ Heinäk $+0.477 \cdot$ Kesäk & $22.361^{* * *}$ & $(3,195)$ & $\begin{array}{l}0.256 \\
(10.4)\end{array}$ \\
\hline Kiri & 16 & $\mathrm{y}=37.681-0.048 \cdot$ July $+0.953 \cdot$ Kesăk $-1.436 \cdot$ Heinäk & $7.214^{* *}$ & $(3,12)$ & $\begin{array}{l}0.643 \\
(25.3)\end{array}$ \\
\hline Hemmo & 37 & $\mathrm{y}=49.347-0.048 \cdot$ July -1.339 .Heinäk & $6.791^{* *}$ & $(2,34)$ & $\begin{array}{l}0.285 \\
(16.3)\end{array}$ \\
\hline Rondo & 36 & $\mathrm{y}=38.524-0.036 \cdot$ July $-0.908 \cdot$ Heinäk & $6.283^{* *}$ & $(2,33)$ & $\begin{array}{l}0.276 \\
(17.5)\end{array}$ \\
\hline Proco & 39 & $y=16.427-0.034 \cdot$ July $+0.528 \cdot$ Kesäk & $8.922 * * *$ & $(2,36)$ & $\begin{array}{l}0.331 \\
(24.4)\end{array}$ \\
\hline Simo & 15 & $y=26.815-0.025 . J u l y$ & $7.730^{*}$ & $(1,13)$ & 0.373 \\
\hline Hertta & 23 & all variables & 2.254n.s. & $(6,16)$ & 0.458 \\
\hline Filby & 33 & $\begin{aligned} \mathrm{y}= & 44.265-0.032 \cdot \text { July }-0.983 \cdot \text { Heinäk }+0.317 \cdot \text { Kesäk } \\
& -0.600 \cdot \text { Elok }+0.007 \cdot \text { August }-0.006 \cdot \text { June }\end{aligned}$ & $3.027^{*}$ & $(6,26)$ & 0.411 \\
\hline
\end{tabular}

Independent variables: Kesäk, Heinäk, Elok $=$ mean temperatures, ${ }^{\circ} \mathrm{C}$, in June, July and August June, July, August = precipitations, mm, in June, July and August

and temperature, accounted for $33.1 \%$ of the total variation in protein content.

Regression model computed through Simo revealed that July precipitation alone accounted for $37.3 \%$ of the total variation in protein content, and no other variables were entered into the model. Cultivar Kiri showed quite a different pattern compared with Simo since the regression model included July precipitation and June and July mean temperatures, which accounted for $64.3 \%$ of the protein variation. Of these variables, July precipitation accounted for $25.3 \%$. However, it must be pointed out that computations on Kiri and Simo based on a rather limited number of trials. For most cultivars the regression model explained protein variation statistically significantly, except for Hertta, an old and long-stemmed cultivar and Filby, a leafless type. Computations through Hertta indicated that neither a single factor nor all together explained significantly the variation in protein content. In the case of Filby, single factors did not explain the variation, but when all variables were entered into the model, the equation explained for $41.1 \%$ of the variation in protein content.

At the second stage of computations tem- perature sum was added into the model. In general, temperature sum had a significant effect on protein content (Table 4), and in most cases this variable removed the mean temperatures from the equation. According to the data based on all varieties, the regression model including temperature sum, June and July precipitation accounted for $62.9 \%$ of the variation in protein content. Of these variables temperature sum alone accounted for $43.3 \%$ of the protein variation. In general, when the temperature sum was added into the regression model, the number of trials diminished considerably, and hence the results of single varieties suffer from the lack of representativeness. In most cases, in addition to temperature sum, June and July precipitation were important variables explaining for most of the variation in protein content thus confirming the previous model. In general the $\mathbf{R}^{2}$ values varied from $39 \%$ to $69.8 \%$.

\section{Discussion}

\section{Factors affecting protein content in peas}

The data reported in this study emphasize the important role of weather conditions for 
Table 4. Regression analysis on climatic factors affecting protein content in peas from the data based on official cultivar trials at six locations in Southern Finland in 1978-85.

\begin{tabular}{|c|c|c|c|c|c|}
\hline Cultivars & $\mathrm{n}$ & Regression equation (probability of $\mathrm{F}$ in $=0.050$ ) & F value & df & $\mathbf{R}^{2}$ \\
\hline $\begin{array}{l}\text { tot. data } \\
\text { ( } 7 \text { culti- } \\
\text { vars) }\end{array}$ & 103 & $\mathrm{y}=8.304+0.019 \cdot \mathrm{ts}-0.034$. June -0.023 . July & $56.057^{* * *}$ & $(3,99)$ & $\begin{array}{l}0.629 \\
(43.3)\end{array}$ \\
\hline Kiri & 7 & $y=-13.312+0.038$ ts & $10.899^{*}$ & $(1,5)$ & 0.686 \\
\hline Hemmo & 20 & $y=10.576+0.017 \cdot \mathrm{ts}-0.035$. June $-0.024 . J u l y$ & $10.398 * * *$ & $(3,16)$ & 0.661 \\
\hline Rondo & 18 & $\mathrm{y}=24.054-0.049$. June & $10.250^{* *}$ & $(1,16)$ & 0.390 \\
\hline Proco & 21 & $\mathrm{y}=25.421-0.034$. July -0.037 . June & $10.545^{* * *}$ & $(2,18)$ & 0.540 \\
\hline Simo & 6 & - & & & \\
\hline Hertta & 12 & $\mathrm{y}=29.073-0.068$. June & $23.084^{* * *}$ & $(1,10)$ & 0.698 \\
\hline Filby & 19 & - & 1.968 n.s. & $(7,11)$ & 0.556 \\
\hline
\end{tabular}

Independent variables: Kesäk, Heinäk, Elok = mean temperatures, ${ }^{\circ} \mathrm{C}$, in June, July and August June, July, August = precipitations, mm, in June, July and August

ts $\quad=$ temperature sum

protein variation in peas under northern conditions. It was found that July precipitation in particular decreased protein content, while high June temperature increased it. These results are in accordance with a previous study by KaRJALAinen and Hovinen (1981), which, however, was made of one cultivar only. It seems apparent that temperatures during and after flowering as we!l as at the beginning of seed development are crucial for final protein accumulation into the pea seed under Finnish conditions. It is known (review by BRIARTY 1978) that part of the supply of nitrogen into the developing fruit is dependent on assimilation before flowering, but the majority of the nitrogen supply depends on assimilation after flowering.

The positive effect of temperature on protein content was further emphasized when temperature sum was incorporated into the model. For example, in the data where all varieties were included, temperature sum alone explained for $43.3 \%$ of the total variation in protein content. However, this study also clearly indicated that rainfall has negative effect on protein content. It seems evident that precipitation in July is the most limiting factor for protein accumulation in peas under Finnish conditions.

Rainfall is known to influence pea devel- opment in many ways (e.g. Multamäkı 1961), and excessive rains in July are particularly critical for the vegetative development as humidity prolongs flowering time and thereby impedes the onset of seed development. Thus it is obvious that rainfall in July is not merely harmful for reliable seed yields but also decreases the protein content in pea seed.

The present regression computations over all varieties indicated that climatic factors accounted for $25.6 \%$ in the first model and $62.9 \%$ in the second model of the total variation in protein content. Consequently, these computations clearly show that climatic factors have decisive effects on protein content under northern conditions. These results support other studies (ALI-Khan and YoungS 1973, Wolf 1975, Múller and GotTschalk 1978, Snoad 1980, Matthews and Arthur 1985), which also emphasize the role of environmental factors affecting protein content more than heritable factors. However, protein content in peas is affected by many other factors, too. Soil fertility, particularly nitrogen level, microclimatic conditions and latitude (Ali-Khan and Youngs 1973, Gottschalk 1976, McLean et al. 1974, Trevino and MurRAY 1975) as well as sowing time (ALI-KHAN 1977) have been reported to affect protein content. 
Implications for protein improvement in peas by plant breeding

Successful breeding for protein improvement requires sufficient genetic variation in protein content and rapid and reliable methods of protein determination to be used for screening large numbers of progenies. Further, it is important that there are not many negative correlations between protein content and other agronomic characters, and they should be breakable by breeding.

Heritability calculations provide estimates of the proportions of genetic and environmental variation in the total variation. Thus heritability is a predictor of the success a plant breeder can expect to attain from selection (Frey 1977). Table 5 summarizes the main results of heritability studies carried out of the protein content of peas. In general, heritability values vary largely from $17 \%$ to $70 \%$, depending on parent material, experimental design, and particularly calculation methods. However, the majority of available data shows moderately high heritability values, thus suggesting that selection for protein content in peas should be quite successful. However, doubts have been presented, and according to SNOAD (1980), for instance, there is little evidence of successful protein improvement compared with that of seed yield. This conclusion is in accordance with our previous study (KARJALAinen and Hovinen 1981) as well as with a recent review by MATthews and Arthur (1985).

Variation in the protein content of peas is wide, from $14 \%$ to $39 \%$ (BLixt 1979). The heritability values presented in Table 4 show that part of the variation is due to genetic factors, but a large part appears to be due to nongenetic factors. In view of selection efficiency it is important that the protein content of peas can vary widely in pods taken from different parts of the plant (MATthews and ARTHUR 1985). Similar findings have been made with beans (Woolfe and Hamblin 1974). The results imply that the reliable determination of protein content in segregation populations requires a large number of samplings in order to reveal heritable differences between progenies. An even greater part of protein variation caused by non-genetic components appears to be due to various environmental factors. The data reported in this study indicated that even half of the protein variation was accounted for by climatic factors. This result is in accordance with our previous study (KARJALAINEN and HoviNEN 1981) and it clearly indicates that protein levels even in single cultivars vary widely under northern conditions between different regions and years. These results fit well the recent study by MatTHEwS and Arthur (1985) as they have also pointed out that genetic variation in protein content of peas is almost completely swamped by unpredictable environmental variables. Consequently it is apparent that breeding new cultivars for variable northern conditions with high and stable levels of protein is a difficult task. In a previous study KARJALAINEN and Hovinen (1981) demonstrated that protein yield per hectare was almost totally determined for by variation in seed yield, and according to these lines of evidence they sug-

Table 5. Summary of heritability percentages for protein content in peas as reported by various authors. Heritability values in some cases presented in broad sense (b.s) and narrow sense (n.s).

\begin{tabular}{llc}
\hline Author & Method of calculation & Heritability $\%$ \\
\hline Pandey and Gritton 1975 & Diallel, comp. var. & $54-67$ b.s. \\
& & $45-67$ n.s. \\
Pandey and Gritton 1976 & F1, F2 pop. regression & $17-56$ \\
Scwiecicki et al. 1980 & F1, F2 pop. regression & $29-70$ \\
Scwiecicki et al. 1981 & Diallel, comp. var. & 92 b.s. \\
& & 75 n.s. \\
\hline
\end{tabular}


gested that in breeding for better protein productivity it is much more effective to improve seed yield and yield stability than protein content.

Protein improvement by plant breeding has frequently faced difficulties because either protein content or protein quality is negatively associated with agronomic characters (FREY 1977, RABSON et al. 1978). Negative associations between protein content and grain yield in peas do not appear to be as tight as in cereals (Evans and Gridley 1979). However, negative (Jermyn and Slinkard 1977, BingeFORS et al. 1979, KARJALAINEN and Hovinen 1981) as well as positive correlations (ALIKhan and Youngs 1973, Pandey and Gritton 1976) between protein content and seed yield have been found. The present data as well as observations by GoTTSCHALK et al. (1975) suggest that seed weight is weakly associated with protein content. In some cases late maturation time appears to be positively associated with protein content as suggested by this study and earlier data (KarJalainen and Hovinen 1981).

\section{References}

Alı-Khan, S.T. 1977. Seed yield, seed weight, percent protein and protein yield of field peas as affected by seeding dates. Can. J. Plant Sci. 57: 17-20.

-, \& Youngs, C.G. 1973. Variation of protein content in field peas. Can. J. Plant Sci. 53: 37-41.

Bingefors, S., Quittenbaum, G. \& Tapia-Rojas, J. 1979. Proteinhaltsvariationer i ärter. Sver. Utsädesför. Tidskr. 89: 189-208.

Bц.xт, S. 1979. Natural and induced variability for seed protein in temperate legumes. In Seed protein improvement in cereals and grain legumes. (Proc. Meet. Neuherberg, 1978), IAEA, Vienna (1979) II, p. 3-20.

BriarTY, L.G. 1978. The mechanisms of protein body deposition in legumes and cereals. In Plant Proteins (ed. by G. Norton), p. 81-98. Butterworths, London.

Davies, D.R. 1977. Restructuring the pea plant. Sci Progress 28: 235-241.

Evans, A.M. \& Gridley, H.E. 1979. Prospect for the improvement of protein and yield in grain legumes. Curr. Adv. Plant Sci. 32: 1-17.

FreY, K.J. 1977. Protein of oats. Z. Pflanzenzücht. 78: 185-215.

Gottschalk, W. 1976. Further investigations on the genetic control of seed protein production in Pisum mutants. In Evaluation of seed protein alterations by mutation breeding. (Proc. Meet. Hahnenklee, 1975), IAEA, Vienna (1976) p. 157-177.

-, Moller, H.P. \& Wolf, G. 1975. Relations between protein production, protein quality and environmental factors in Pisum mutants. In Breeding for seed protein improvement using nuclear techniques. (Proc. Meet. Ibadan, 1973), IAEA, Vienna (1975), p. 105-123.

Holt, N.W. \& SosulsKı, F.W. 1979. Amino acid composition and protein quality of field peas. Can. J. Plant Sci. 59: $653-660$.

Jermyn, W.A. \& Slinkard, E.A. 1977. Variability of protein percent and its relationship to seed yield and seed shape in peas. Legume Res. 1: 33-37.
Karjalainen, R. \& Hovinen, S. 1981. Variation in protein content of peas under Finnish conditions. J. Scient. Agric. Soc. Finl. 53: 228-238.

Kujal.A, V. 1953. Felderbse, bei welcher die ganze Blattspreite in Ranken umgewandelt ist. Arch. Soc. Zool. Bot. Fenn. 8: 44-45.

Matthews, P. \& Arthur, E. 1985. Genetic and environmental components of variation in protein content in peas. In the Pea Crop, A Basis for the Improvement (ed. by P.D. Hebblethwaite, M.C. Heath \& T.C.K. Dawkins), p. 369-381. Butterworths, London.

Mclean, L.A., Sosulski, F.W. \& Youngs, C.G. 1974. Effects of nitrogen and moisture on yield and protein in field peas. Can. J. Plant Sci. 54: 301-305.

MultamÄкı, K. 1961. Der Einfluss Klimatischer Factoren auf die Entwicklung von Erbse. Maat. Tiet. Aikak. 33: 256-266.

Múller, H.P. \& GotTschal., W. 1978. Gene-ecological investigations on the protein production of different Pisum genotypes. In Seed protein improvement by nuclear techniques (Proc. Meet. Bader, 1977), IAEA, Vienna (1978), p. 301-314.

Pandey, S. \& Gritton, E.T. 1975. Inheritance of protein and other agronomic traits in a diallel cross on pea. $\mathbf{J}$. Am. Soc. Hort. Sci. 100: 87-90.

,- 1976 . Observed and predicted response to selection for protein and yield in peas. Crop Sci. 16: 298-292.

Pesola, V. 1955. Protein content of field pea seeds as a varietal character. Acta Agr. Fenn. 83: 125-132.

Swiecickı, W.K., Kaczmarek, Z. \& Surma, M. 1980. Inheritance of protein in peas. II. Heritability of protein content in Ranger $\times$ Strål and Paloma $\times$ Strál crosses. Pisum Newsletter 12: 68-69.

,- 1981 . Diallel analysis of protein content in selected lines of pea (Pisum sativum L.). Genetica Polonica 22: $78-84$.

SNOAD, B. 1980. The origin, performance and breeding of leafless peas. Adas Quart. Rev. 37: 69-86. 
Rabson, R., Bhatia, C. \& Mitra, R.K. 1978. Crop productivity, grain protein and energy. In Seed protein improvement by nuclear techniques. (Proc. Meet. Bader, 1977), IAEA, Vienna (1978) p. 3-20.

Trevino, I.C. \& Murray, G.A. 1975. Nitrogen effects on growth, seed yield, and protein of seven pea cultivars. Crop Sci. 15: 500-502.

\section{SELOSTUS}

\section{Herneen proteiinipitoisuuden muuntelu kasvinjalostuksen näkökulmasta}

\section{Reijo Karjalainen}

Kasvipatologian ja kasvinjalostustieteen laitokset Helsingin yliopisto, $00710 \mathrm{Helsinki}$

\section{Salme Kortet}

Kasvinjalostusosasto, Maatalouden tutkimuskeskus, 31600 Jokioinen

Herneen proteiinipitoisuuden vaihtelua tutkittiin virallisten lajikekokeiden perusteella kuudella koepaikalla vuosina 1978-1985. Korrelaatio- ja askeltavalla regressioanalyysillă selvitettiin tärkeimpien ilmastotekijöiden vaikutusta herneen proteiinipitoisuuteen.

Korrelaatioanalyysit osoittivat, että valkuaispitoisuus kytkeytyi positiivisesti lämpötilasummaan ja kesäkuun keskilämpötilaan mutta negatiivisesti heinäkuun sademảă-
WoLf, G. 1975. Quantitative Untersuchungen über den Proteingehalt von Samen von Pisum sativum. Z. Pflanzenzücht. 75: 43-54.

Woolfe, J.A. \& Hamblin, J. 1974. Within and between genotypes variation in crude protein content of Phaseolus vulgaris L. Euphytica 23: 121-128. räăn. Regressioanalyysit osoittivat, että ilmastotekijăt selittivăt $25-70 \%$ herneen proteiinipitoisuuden vaihtelusta. Lämpötilasumma ja heinäkuun sademäärä selittivăt eniten herneen valkuaispitoisuuden vaihtelua. Tulokset viittaavat siihen, että pohjoisissa kasvuoloissa herneen perinnölliset valkuaispitoisuuden erot peittyvăt usein ympäristötekijöiden vaikutusten alle, joten proteiinipitoisuuden parantaminen kasvinjalostuksen keinoin on vaikeaa. 